\title{
THE INTERNATIONALIZATION OF SMES IN GENTRAL EUROPE AND ITS IMPACT ON THEIR METHODS OF RISK MANAGEMENT
}

\author{
Zuzana Virglerova ${ }^{1}$, Muhammad Asif Khan ${ }^{2 *}$, \\ Raimonda Martinkute-Kauliene ${ }^{3}$ and Sandor Kovács ${ }^{4}$ \\ ${ }^{1)}$ Tomas Bata University in Zlín, Czech Republic \\ ${ }^{2)}$ University of Kotli, Jammu and Kashmir, Pakistan \\ 3) Vilnius Gediminas Technical University, Lithuania \\ 4) University of Debrecen, Hungary
}

Please cite this article as:

Virglerova, Z., Khan, M.A., Martinkute-Kauliene, R. and Kovács, S., 2020. The Internationalization of SMEs in Central Europe and Its Impact on Their Methods of Risk Management. Amfiteatru Economic, 22(55), pp. 792-807.

\section{Article History:}

Received: 30 March 2020

Revised: 8 May 2020

Accepted: 20 June 2020

\section{DOI: $10.24818 / \mathrm{EA} / 2020 / 55 / 792$}

\begin{abstract}
The international business environment is very competitive, and enterprises should be aware of how to manage business risks, which methods to choose, and what impact these risks have on the sustainability of these methods and on the whole system. The aim of this article is to analyse the impact of the internationalization of SMEs on risk management and define the differences in perceptions of the importance of sustainability regarding this system. Data from an extensive research study in V4 countries (Czech Republic, Hungary Slovakia, Poland) were analysed. Data were collected through on-line questionnaire in 2018, and a total of 1781 valid responses by SMEs were included in this research. To fulfil the research aim, three hypotheses were established. The odds ratio was calculated for the effect of company type (international $x$ domestic) on the different individuals responsible for risk management. The Tarantula similarity measure was calculated to measure the strength and pairwise relationships between risk reducing strategies and risk management techniques. The Chi-Square test was applied to assess differences between variables. The results show that a specialized risk manager is authorized to deal with risk management in international companies more often than in domestic companies. There are also differences in the relationship between risk managing techniques and risk reducing strategies, depending on the presence of the business on international market. Companies in the international market are more focused on methods of risk management which support sustainability and their system of risk management has a more stable future.
\end{abstract}

Keywords: risk manager, V4 (Czech Republic, Hungary Slovakia, Poland), enterprise, risk management, ERM, sustainability

JEL Classification: F23, G32, L26, M16

\footnotetext{
* Corresponding author, Muhammad Asif Khan - khanasif82@ hotmail.com
} 


\section{Introduction}

Enterprise risk management (ERM) has become more important in the last few decades. Companies realize that their internal systems are more vulnerable without a potential risk analysis and an implementation of the appropriate methods for risk management. Dabari and Saidin (2014) and Meyer (2013) argued that risk management is essential for a corporate organization because it gives the firm support in the enforcement and review of its policies.

Especially for small and medium enterprises, functional risk management can be a crucial aspect of their business in times of crisis. Dvorský et al. (2018a) state that SMEs perceive business risks more intensively now than in the pre-crisis era. Koval'ová et al. (2018) explains the main reasons for the high vulnerability of SMEs to risks. These reasons can be defined as obsolete technology, low levels of experience, insufficient capital, a lack of managerial capacities, a low utilization of existing capacities and insufficient financial resources. Kot and Dragon (2015) found that the success of risk management is connected to financial success. Florio and Leoni (2017) point out that companies with a high level of implementation of risk management have a better financial performance and market value.

The need to implement functional risk management increases on the international markets. International projects are riskier than projects carried out on domestic markets because they take place in environments characterized by economic, social, legal, political and cultural differences which can significantly affect the financial performance of the company (Meyer et al. 2017, Park et al., 2014; Javernick-Will and Scott, 2010).

Top management should identify an individual who will be responsible for risk management. Without management, implementing sustainability practices tends to be unsuccessful. However, management should be the supervisor of the implementation and not an active element in this process (Aziz et al., 2015; Wijethilake and Lama, 2019; Woods, 2009). Henschel's (2006) study among German companies found out that the influence of management decreases with company size.

It is generally expected that companies which enter the international market face different risks than companies active only on national markets. However, an analysis of the differences among companies' assessment of risk management and the methods used in this process is lacking. The aim of the article is to analyse the impact of the internationalization of SMEs in V4 countries on risk management and discuss its sustainability.

The article is structured as follows. The first part describes the theoretical background of the business environment of SMEs and enterprise risk management. A description of the research methodology follows, in order to define the aim of the article, the hypotheses, the data and the methods used for their evaluation. The next section presents the results, which are discussed in terms of sustainability. The paper concludes with a summary of the results and a definition of its limitations and an outline for future research.

\section{Review of the academic literature}

Borocki et al., (2019) and Grigore and Drăgan (2015) claim that the highly dynamic and intense changes in the business ecosystem, as well as the need to obtain and maintain a competitive position, compel enterprises to adopt the most appropriate business strategies. 
This, however, covers a very wide field. The goal of ERM is to search for opportunities and recognize them during upturns, and also to protect the business against risks during downturns. ERM supports operational and strategic management decisions and also offers a competitive advantage for enterprises (Nocco and Stulz, 2006; Stroh, 2005). ERM covers some purposeful activities, from risk prevention and risk management to limiting the amount of damage that can occur.

For SMEs, which are the backbone of the world economy, effective risk management can represent a major protection against default, especially in times of crisis. Economic progress, especially in developing countries, is conditioned by the survival of small and medium enterprises (Mura and Kljucnikov, 2018; Al Mamun et al., 2017, Šebestová and Sroka, 2020). Many researchers have focused on the area of risks and risk management of SMEs (e.g. Cepel et al, 2018; Hudakova et al., 2018; Kozubíková et al. 2017; Oláh et al., 2019a; Oláh et al., 2019b; Dvorský et al., 2018b; Rahman et al., 2017). The research has shown that risk management practices in SMEs are very informal, which inhibits the building of risk management capacity in SMEs (Gao et al., 2013; Poba-Nzaou et al., 2014). However, Brustbauer (2016) found numerous examples of SMEs that take a very proactive approach to risk management. Terungwa (2012) states that the inability of business owners to adopt the processes of risk management leads to a decrease in the sustainability of SMEs. The results of research conducted by Kljucnikov et al. (2019) show that security management in the case of risk management plays a very important role in the protection of information as the most valuable asset of the company in SMEs. In this context, Ragnedda et. al. (2019) warn that it is very important to perceive digital capital as one of the socioeconomic factors that influence individual decision-making.

Non-effective risk assessment and management is a critical obstacle to success in international projects (Zhao et al., 2015). If international companies implement risk management effectively, it helps not only in risk reduction but also in achieving competitive advantage and improving company performance (Deng et al., 2014; Mura, 2019). Frimpong et al. (2003) and Jafari (2013) point out that the ability to identify technical risks in projects in developing countries influences the technical performance of these projects. One way in which international companies can invest in improving their risk management is to obtain valuable resources which reduce the consequences of risks during the international project. Another way is to innovate the processes and constantly improve the qualifications of employees (Du et al., 2016; Hajduová et al., 2014). Kot and Dragon (2015) highlighted that international companies which operate on financial markets are affected by changes in the business environment more than domestic companies. They cannot be active on the international market without an effective evaluation of risks. These companies are forced to treat risk management as a regular part of the company's policy.

SMEs sometimes identify all potential risks, but they focus only on the most important risks and train their employees to manage these risks effectively (Bruns and Fletcher, 2008; Sukumar et al., 2011). In companies where a business owner dominates or where there is no professional manager, risk management is not appropriate. This may be particularly evident in family-owned firms (Lovata and Costigan, 2002; Paape and Speklé, 2012). An entrepreneur's perception of risks and the ability to manage them, contingent upon personal and company-related resources, influences the respective risk-management approach (Herbane, 2010; Leopoulos, 2006; Nocco and Stulz, 2006, Zainol et al., 2018). In the research of Henschel (2006) related to German SMEs, it was found that in more than half 
of SMEs risk management is organized by management together with a specific department. Another frequent option is when risk management is in the hands of management, controlling departments or designated employees of business units. Only $3 \%$ of the SMEs studied have an internal audit.

The first hypothesis was formulated to find out how the selection of the person responsible for risk management differs in international and national companies.

H1: International companies are more likely to employ a specialized manager who is in charge of risk management, compared to domestic companies who prefer to risks to be handled by the owner of the company, as there is no designated individual for this task.

The methods of risk analysis are divided into two groups - qualitative and quantitative methods (McNeill, 2005, Merna and Al-Thani, 2007). Qualitative methods are characterized by risks being expressed in varying degrees (for example, they are scored from 1 to 10, or determined verbally - small, medium, large). Qualitative methods are simpler and faster, but more subjective. Qualitative methods include brainstorming, the Delphi method, interviews, matrix risk diagrams, etc. Quantitative methods are based on the mathematical calculation of the risk from the frequency of the threat and its impact. They usually express the impact in monetary units (annual projected losses). They are more exact than qualitative methods, but they are also more time-consuming. The disadvantage is their difficulty and often a highly formalized procedure. Quantitative methods are methods such as: CRAMM, @RISK, RiskPAC, RiskWatch (Yadav and Jain, 2014). The qualitative study by Cioccio and Michael (2007) from Australia showed that small enterprises mostly use insurance as the primary tool for risk management. However, insurance is sometimes associated with considerable costs and is basically used for covering certain unexpected events. Weber (2000) and Rauch et al. (2000) in this context state that in Germany the quality of planning is positively related to success. SMEs in Germany use business planning to reduce uncertainty. Planning has a rather short time horizon and is not carried out in great detail. A frequent error made in business planning is to have no written business plan. The plan often only exists in the mind of the owner-manager. Nikolova and Linkova (2011) found out that a diversification of risks is a common method for risk reduction in the agriculture sector in Bulgaria and Romania. Witt (2008) and Davies (2006) reported an increasing importance of risk transferring in case of private companies.

Enterprises should implement methods which are sustainable. Risks can be mitigated by various approaches, such as producing sustainability reports, and proactively adapting to changes in sustainability rules, regulations and governments policies (Anderson and Anderson, 2009). The proactive approach to sustainability tends to integrate corporate risk management more effectively and can be a key competitive advantage in the process of the internationalization of companies (Aziz et al., 2015).

Two hypotheses were formulated to find out how the selection of risk management methods differs in international and national companies.

H2: The structure of the risk reducing strategies applied, as well as the risk managing techniques used is different among SMEs with respect to company type, as international companies transfer risk to partners (e.g. outsourcing) more often and are faced with different sources of risk. 
H3: Some risk reducing strategies require different risk managing techniques with respect to company type, and the relationship between risk managing techniques and risk reducing strategies is different among international and domestic companies.

\section{Research methodology}

The aim of the article is to analyse the impact of the internationalization of SMEs in V4 countries on risk management and discuss its sustainability. Data from international research carried out in 2018 were used. Companies were chosen randomly from national databases and were addressed directly by e-mail and asked to complete the questionnaire in electronic form. The questionnaire was translated into the national language of each state for perfect understanding. The questions were divided into two parts. The first part analysed social and demographic factors such as the gender and age of the entrepreneurs, their education, the size of the enterprise, the area and region of the business and the length of its activity. The second part asked for an assessment of the importance of the risks and methods of risk management.

The so-called Tarantula similarity measure (Choi et al., 2010; Jones and Harrold, 2005) was calculated to measure the strength of pairwise relationships between risk reducing strategies and risk managing techniques.

The Tarantula measure calculates the relative risk, which is the relative probability of applying a given risk managing technique on the condition that a given risk reducing strategy is applied, compared to the relative probability of applying the risk managing technique provided that the risk reducing strategy is not applied (Choi et al., 2010; Jones and Harrold, 2005)

$[a /(a+b)] /[c /(c+d)]$

It has a value of 1 in the case of independent factors if $a=b=c=d$, and a large value (a positive relationship between the two factors) when $c+b$ is close to 0 ), and 0 when $a=d=0$ (two factors are negatively correlated).

We calculated the odds ratio (OR) for the effect of company type (international against domestic) on the occurrence of the individual responsible for risk managing, risk managing techniques and risk reducing strategies. The Standard Error (SE) and p-value and the zvalue is calculated according to Sheskin (2004) as:

$\ln (\mathrm{OR}) / \mathrm{SE}\{\ln (\mathrm{OR})\}$

The Chi-Square test was applied to assess differences between domestic and international companies regarding the distribution of risk reducing strategies/risk managing techniques. Hence, the test is performed on a crosstable with two columns for the company type and 7 (or 6 rows) for risk reducing strategies (or risk managing techniques) including other categories. The requirement for the analysis is that the proportion of cells having fewer than 5 data items should not exceed 20\% (Spiegel and Stephens, 2008). When the probability of error (significance) is lower than 0.05 (significance level), the null hypothesis, i.e. that the two distributions are identical among the different types of companies, can be rejected with a low error rate. 


\section{Results and discussion}

The sample consisted of 408 responses from SMEs in the Czech Republic, 487 in Slovakia, 498 in Poland, and 388 in Hungary $(\mathrm{N}=1.781)$. The characteristics of SMEs which were involved in the research in terms of company size and sector can be seen in Table no. 1.

Table no.1. Descriptive statistics of the research sample by Country $(\mathrm{N}=1.781)$

\begin{tabular}{l|c|c|c|c|c}
\hline Factor/category & $\begin{array}{c}\text { Czech } \\
\text { Republic }\end{array}$ & Poland & Hungary & Slovakia & Total \\
\hline Micro company & $64.0 \%$ & $60.0 \%$ & $62.1 \%$ & $64.5 \%$ & $62.6 \%$ \\
Small company & $23.5 \%$ & $0.4 \%$ & $18.6 \%$ & $23.6 \%$ & $16.0 \%$ \\
Medium company & $12.5 \%$ & $39.6 \%$ & $19.3 \%$ & $11.9 \%$ & $21.4 \%$ \\
\hline Industry & $23.5 \%$ & $14.9 \%$ & $10.8 \%$ & $15.6 \%$ & $16.2 \%$ \\
Trade & $23.0 \%$ & $31.7 \%$ & $19.6 \%$ & $24.2 \%$ & $25.0 \%$ \\
Agriculture & $3.7 \%$ & $6.0 \%$ & $16.0 \%$ & $2.3 \%$ & $6.6 \%$ \\
Construction & $15.4 \%$ & $6.8 \%$ & $5.2 \%$ & $12.3 \%$ & $9.9 \%$ \\
Trasportation, logistics & $0.0 \%$ & $11.4 \%$ & $7.2 \%$ & $6.4 \%$ & $6.5 \%$ \\
Tourism, hotel & $6.4 \%$ & $6.2 \%$ & $10.6 \%$ & $8.8 \%$ & $7.9 \%$ \\
and catering & $20.6 \%$ & $17.1 \%$ & $28.9 \%$ & $27.5 \%$ & $23.3 \%$ \\
Other services & $7.4 \%$ & $5.8 \%$ & $1.8 \%$ & $2.9 \%$ & $4.5 \%$ \\
Other sectors & & & & & \\
\hline Length of activity on & & & & & \\
international markets & $63.7 \%$ & $65.1 \%$ & $63.9 \%$ & $47.8 \%$ & $59.8 \%$ \\
$\quad$ No experience & $3.2 \%$ & $5.2 \%$ & $7.0 \%$ & $6.0 \%$ & $5.3 \%$ \\
less than 1 year & $8.6 \%$ & $9.2 \%$ & $8.2 \%$ & $14.2 \%$ & $10.2 \%$ \\
1-5 years & $7.6 \%$ & $9.0 \%$ & $5.9 \%$ & $12.7 \%$ & $9.0 \%$ \\
5-10 years & $16.9 \%$ & $11.4 \%$ & $14.9 \%$ & $19.3 \%$ & $15.6 \%$ \\
\hline more than 10 years & 408 & 498 & 388 & 487 & 1.781 \\
\hline Number of companies & & & & & \\
\hline & & & & & \\
& & & & & \\
& & & & & \\
\hline
\end{tabular}

In terms of the size of the business, the sample contained 1,115 micro businesses $(63 \%)$, 285 small businesses (16\%), and 381 medium-sized businesses (21\%). Regarding the operational activity of the businesses, there were $288(16 \%)$ companies in industry, 446 $(25 \%)$ in trade, $118(7 \%)$ in agriculture, $177(10 \%)$ in construction, $116(6 \%)$ in transport, $141(8 \%)$ in tourism, hotel and catering, and $495(28 \%)$ companies providing other services operating in other sectors. Based on the length of activity on the international market, 1065 $(60 \%)$ had no experience at all, $95(5 \%)$ had less than 1 year, $182(10 \%)$ had 1-5 years, 161 (9\%) had 5-10 years, while $278(16 \%)$ companies had more than 10 years of international experience. 
Significant differences can be found between the ratio of international and domestic companies regarding the employed individual responsible for risk management (Chi2 = $17.39 ; \mathrm{p}<0.01)$. In the case of both company groups the company owner is responsible in 63-68\% of cases for risk management, but domestic companies had a relatively larger proportion of owners with this responsibility (see Figure no. 1). On the other hand, the ratio of companies employing a risk or authorized manager who is responsible for risk management in SMEs is relatively higher among the international companies $(21 \%)$ compared to the domestic companies (7\%), while in case of the domestic companies it more frequently occurs that nobody is in charge (19\%) (these results support H1). These results are very similar to the results of research conducted in Germany by Henschel (2006). The relationship between the individual who is responsible for risk management and the success of the risk management process was proved by Daud et al. (2010) who carried out research on Malaysian companies. They found that the quality of the risk manager strongly influences the quality of the risk management process.

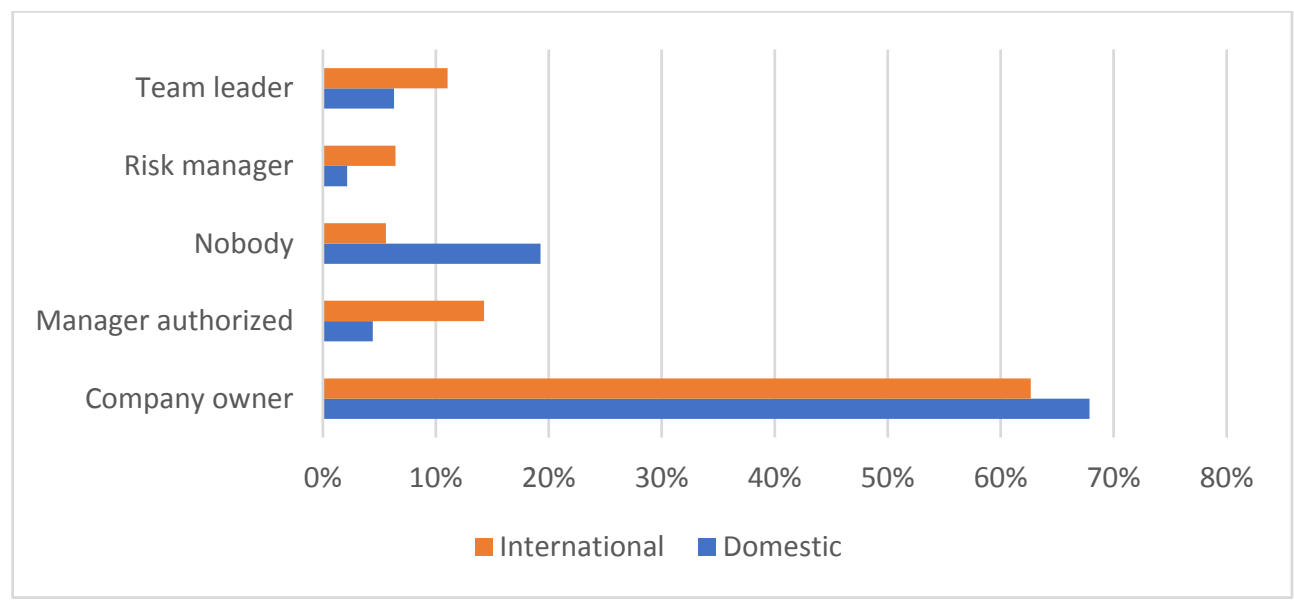

Figure no. 1. Proportion of companies employing a person responsible for risk handling, by international presence

Table no. 2 shows the characteristics of only those companies who have applied a given risk reducing or managing strategy. The distribution of company type and country of origin is given for each factor, respectively. It can be noticed that alternative risk reduction and managing strategies were applied mostly in domestic companies. $67 \%$ of the companies who applied risk avoidance were domestic companies. International companies tend to transfer risk at a much higher rate (among the risk avoiding companies $63 \%$ were international). Planning is more typically a characteristic of an international company than a domestic one. 
Table no. 2. Distribution of companies applying risk reducing strategies and management techniques, by company type and country

\begin{tabular}{|l|c|c|c|c|c|c|}
\hline \multirow{2}{*}{ Factor } & \multicolumn{2}{|c|}{ Company type } & \multicolumn{4}{c|}{ Country } \\
\cline { 2 - 7 } & Domestic & International & $\begin{array}{c}\text { Czech } \\
\text { Republic }\end{array}$ & Poland & Hungary & Slovakia \\
\cline { 2 - 7 } & \% (row wise =100\%) & \multicolumn{4}{|c|}{$\%$ (row wise =100\%) } \\
\hline Insurance & 55 & 45 & $\mathbf{3 4}$ & 19 & 20 & 27 \\
\hline Transfer risk & 37 & $\mathbf{6 3}$ & 25 & 25 & 31 & 19 \\
\hline $\begin{array}{l}\text { Financial } \\
\text { reserves }\end{array}$ & $\mathbf{5 9}$ & 41 & 21 & 19 & 32 & 28 \\
\hline Expansion & 50 & 50 & 25 & 21 & $\mathbf{3 0}$ & 24 \\
\hline Avoid & $\mathbf{6 7}$ & 33 & 20 & 20 & 22 & $\mathbf{3 8}$ \\
\hline Other & $\mathbf{6 4}$ & 36 & 3 & $\mathbf{9 4}$ & 3 & 0 \\
\hline Check goals & $\mathbf{6 0}$ & 40 & $\mathbf{3 2}$ & 18 & 20 & 30 \\
\hline Audit & $\mathbf{5 8}$ & 42 & 16 & $\mathbf{3 1}$ & 22 & $\mathbf{3 1}$ \\
\hline Planning & 42 & $\mathbf{5 8}$ & 11 & $\mathbf{3 3}$ & $\mathbf{3 7}$ & 19 \\
\hline Decision making & 56 & 44 & 10 & 28 & $\mathbf{4 0}$ & 22 \\
\hline $\begin{array}{l}\text { Quality } \\
\text { management }\end{array}$ & 49 & 51 & 11 & 13 & $\mathbf{5 3}$ & 23 \\
\hline $\begin{array}{l}\text { Project } \\
\text { management }\end{array}$ & $\mathbf{6 6}$ & 34 & 12 & 22 & $\mathbf{4 7}$ & 19 \\
\hline Other & $\mathbf{6 5}$ & 35 & 2 & $\mathbf{9 3}$ & 3 & 2 \\
\hline
\end{tabular}

We can also observe some country specific factors. Most of the companies who have applied other risk reducing and managing techniques were Polish. The Czech companies employ insurance at a relatively higher rate and a much larger proportion of the Slovakian firms tend to avoid risk. The Hungarian companies apply expansion relatively more frequently and also quality and project management are applied mostly among the Hungarian companies.

Based on the Chi-squared test, significant differences can be found between the distributions of international and domestic companies among each of the risk reducing strategies and management techniques $(\mathrm{Chi} 2=23.85 ; \mathrm{p}<0.001$ and $\mathrm{Chi} 2=18.06 ; \mathrm{p}=0.005)$. Country differences were also significant regarding risk reduction $(\mathrm{Chi} 2=222.74$; $\mathrm{p}<0.001)$ and risk management $(\mathrm{Chi} 2=250.88$; $\mathrm{p}<0.001)$. We can generally state that domestic companies employ other alternative risk reducing strategies and risk managing techniques at a relatively higher rate and try to avoid risk while international companies transfer risk to partners and tend to apply planning (Table no. 2). This finding supports H2.

Table no. 3 presents the odds ratios of the studied factors for international companies and domestic firms, by country and for the whole V4 group. 
Table no. 3. Odds ratios and country comparisons of the studied factors

\begin{tabular}{|c|c|c|c|c|c|c|}
\hline Factor & $\begin{array}{c}\text { Odds Ratio } \\
\text { for the V4 } \\
\text { group* }\end{array}$ & $\begin{array}{c}\text { Standard } \\
\text { Error }\end{array}$ & $\begin{array}{c}\text { Czech } \\
\text { Republic }\end{array}$ & Poland & Hungary & Slovakia \\
\hline
\end{tabular}

Person in charge of risk management

\begin{tabular}{lcccccc}
\hline $\begin{array}{l}\text { Risk manager } \\
\text { Company }\end{array}$ & $3.111 * * *$ & 0.260 & $2.379 *$ & $2.666 *$ & $2.951 * *$ & $5.499 * *$ \\
$\begin{array}{l}\text { owner } \\
\text { Manager }\end{array}$ & $0.795^{*}$ & 0.101 & $0.588 *$ & 0.974 & $0.524 * *$ & 1.300 \\
$\begin{array}{l}\text { authorized } \\
\text { Team leader }\end{array}$ & $3.598 * * *$ & 0.184 & $2.798 * *$ & $3.623 * * *$ & $3.242 * * *$ & $8.847 * * *$ \\
\hline
\end{tabular}

Strategies for reducing risks

\begin{tabular}{lcccccc}
\hline $\begin{array}{l}\text { Insurance } \\
\text { Transfer risks } \\
\text { to partners }\end{array}$ & $1.294 *$ & 0.104 & 1.252 & 1.000 & 1.135 & $1.814 * *$ \\
$\begin{array}{l}\text { Financial } \\
\text { reserves }\end{array}$ & 1.064 & 0.120 & 0.754 & $1.816^{*}$ & 1.027 & 0.919 \\
$\begin{array}{l}\text { Expansion of } \\
\text { production }\end{array}$ & 1.513 & 0.241 & 1.806 & $2.891 *$ & 0.649 & 2.261 \\
Risk avoiding & $0.650 * * *$ & 0.108 & 0.643 & $0.388^{*} * *$ & 0.782 & $0.535 * * *$ \\
\hline
\end{tabular}

Risk managing techniques

\begin{tabular}{|c|c|c|c|c|c|c|}
\hline Check goals & 0.981 & 0.097 & 1.483 & 0.976 & 0.744 & 0.770 \\
\hline Audit & 1.115 & 0.125 & 1.013 & $0.464 * * *$ & $2.186^{* *}$ & 1.428 \\
\hline Planning & $2.161 * * *$ & 0.218 & 1.176 & $4.804 * * *$ & 1.106 & $7.245 * *$ \\
\hline $\begin{array}{l}\text { Decision } \\
\text { making }\end{array}$ & 1.172 & 0.190 & 0.875 & 1.514 & 0.967 & 1.600 \\
\hline $\begin{array}{l}\text { Quality } \\
\text { management }\end{array}$ & 1.571 & 0.296 & $2.668^{*}$ & 0.930 & 0.996 & $9.508 *$ \\
\hline $\begin{array}{l}\text { Project } \\
\text { management }\end{array}$ & 0.776 & 0.375 & 0.582 & 2.517 & 0.431 & 0.916 \\
\hline
\end{tabular}

Note: *: in favour of international corporations if the odds ratio is significantly greater than 1.

It can be observed from table no. 3 that international companies are approximately 3 times more likely to employ risk managers and 3.6 times more likely to handle risks with an authorized manager from the executive staff, while domestic corporations are 1.26 times more likely $(1 / 0.795=1.26)$ to manage risk through the company owner (H1 was confirmed). Transferring risks to partners is 2.7 times more likely in the case of international corporations compared to domestic companies, but the odds of avoiding risk are $54 \%$ higher $(1.54=1 / 0.650)$ for domestic companies (H2 can be confirmed). Regarding risk managing techniques, the most remarkable difference can be seen with respect to planning, in favour of international companies who place greater (2 times more) emphasis 
on this technique compared to domestic companies. Observing the country differences we can see huge differences in the odds ratios. For example, planning is extremely important, especially for the Polish and Slovakian international companies, and while quality management is of great importance in the case of the Slovakian international companies, audit is more important for the Hungarian international companies. The Slovakian international companies are somewhat different to other countries' companies, as handling risks with a specialized manager is relatively more important to them.

In the case of international companies, the relative probability of applying quality management, project management, and especially planning, is higher (Table no. 4) when transferring risk is employed to reduce risks ( $\mathrm{H} 3$ can be confirmed).

Table no. 4. The relationship between risk managing techniques and risk reducing strategies*

\begin{tabular}{lcccccc}
\hline \multicolumn{7}{c}{ International corporations } \\
Factor & Goals & Audit & Planning & $\begin{array}{c}\text { Decision } \\
\text { making }\end{array}$ & $\begin{array}{c}\text { Quality } \\
\text { management }\end{array}$ & $\begin{array}{c}\text { Project } \\
\text { management }\end{array}$ \\
\hline Insurance & 1.48 & 1.02 & 0.40 & 0.69 & 0.80 & 0.73 \\
Transfer risks & 0.66 & 1.12 & $\mathbf{2 . 6 4}$ & 1.24 & $\mathbf{4 . 1 4}$ & $\mathbf{4 . 6 0}$ \\
Financial reserves & 0.82 & 1.22 & 1.65 & 1.37 & 1.00 & $\mathbf{2 . 1 7}$ \\
Expansion of & & & & & & \\
production & 0.71 & 1.18 & $\mathbf{2 . 8 7}$ & 0.36 & $\mathbf{2 . 7 0}$ & 0.01 \\
Avoiding risks & 1.07 & 0.92 & 1.08 & 1.08 & 0.60 & 0.67 \\
\hline
\end{tabular}

\section{Domestic corporations}

\begin{tabular}{lcccccc}
\hline Factor & Goals & Audit & Planning & $\begin{array}{c}\text { Decision } \\
\text { making }\end{array}$ & $\begin{array}{c}\text { Quality } \\
\text { management }\end{array}$ & $\begin{array}{c}\text { Project } \\
\text { management }\end{array}$ \\
\hline Insurance & 1.27 & 1.23 & 0.78 & 0.65 & 1.10 & 0.26 \\
Transfer risks & 0.73 & 1.85 & 0.01 & $\mathbf{2 . 5 4}$ & $\mathbf{2 . 5 0}$ & $\mathbf{2 . 7 5}$ \\
$\begin{array}{l}\text { Financial reserves } \\
\text { Expansion of }\end{array}$ & 1.07 & 1.01 & 1.45 & 1.69 & $\mathbf{2 . 1 6}$ & 0.43 \\
production & 1.22 & 0.47 & 3.36 & 1.79 & 1.30 & 0.01 \\
Avoiding risks & 1.03 & 0.76 & 0.70 & 0.81 & 0.69 & $\mathbf{3 . 9 0}$ \\
\hline
\end{tabular}

Note: *: values are odds ratios calculated according the Tarantula similarity index, values greater than 1 indicate co-occurence

Also the expansion of production increases the relative probability of quality management and planning. Quality management covers FMEA (Failure Mode and Effects Analysis) which identifies potential failure models and eliminates the failures during the production. It is considered a model which reduces waste materials and conserves non-renewable resources. Companies active on the international market pay more attention to quality management. This method is considered as sustainable and this finding is in accordance with Lo and Liu (2018) and Bilan et al. (2017). Regarding domestic companies, risk transfer has also a strong relationship with quality and project management, but also with decision making. There are other differences between the two company groups. Regarding domestic corporations, avoiding risks increases the probability of applying project management 3.9 times, and quality management is 2.16 times more likely to be applied 
when financial reserves are employed to reduce risks (This result also supports H3). The financial reserve is also important for SMEs in Romania, where 90\% of SMEs are selffinanced because of the inefficiency of the funding system. SMEs are more likely to create a financial reserve than large companies.

\section{Conclusions}

The aim of this article was to analyse the impact of the internationalization of SMEs on risk management and define the difference in perceptions of the importance of sustainability regarding this system. Three hypotheses were established to evaluate the influence of the internationalization of the company on the risk management process.

We determined odds ratios of the occurrence of the studied factors (the individual in charge of risk management, risk reducing strategies and risk managing techniques) for international companies against domestic firms, by country and for the whole V4 group. The Tarantula similarity measure was also used to study the relationships between risk reducing strategies and risk managing techniques for each company type.

In the case of international companies the chance that there is a specialized risk manager from the executive staff who handled risks is 3 times more likely, and the presence of an authorized manager is 3.6 times more likely compared to companies which are active only on the national market. However, the specialized risk manager is very rare in SMEs inside the V4 (6\% of international companies, $2 \%$ of domestic companies). The owner of the company was found to be responsible for risk management in $63 \%$ of international companies, and $68 \%$ of domestic companies, and the odds of risk being managed throughout the company by the owner are $26 \%$ higher for domestic companies. Interestingly, approximately one fifth of the domestic companies had nobody in charge of risk management at all. These results are in accordance with the results found by Aziz et al., (2015) and Wijethilake and Lama (2019). According to their results, the management of the company should be only a supervisor in case of sustainable risk management.

As regards the structure of risk reduction and managing strategies among international and domestic companies, we stated that alternative techniques were applied, mostly in domestic companies. The odds of avoiding risk were also 54\% higher for domestic companies. International companies tend to transfer risk at odds of 2.7. Planning is 2.16 times more likely in the case of an international company than a domestic one. Regarding country specific differences, planning was extremely important, especially for the Polish and Slovakian international companies, and while quality management was of great importance in case of the Slovakian international companies, audit was more important for the Hungarian international companies. There is also a difference in the relationship between risk managing techniques and risk reduction strategies with respect to the presence on the international market. International companies preferred planning, quality and project management techniques when transferring risk to partners. International companies are more likely to use methods of quality risk management such as FMEA and focus their risk management methods on the concept of sustainability, as well. Domestic companies were more likely to apply project management when avoiding risks and quality management when a financial reserves strategy was employed.

Although the research has produced interesting results regarding the internationalization of SMEs and the methods used for risk management regarding sustainability, there are some 
limitations of the research. The results of V4 countries were analysed. The questionnaire was administered in the official language of each country; however, misunderstanding of the questions can influence the results. The questionnaire should be completed by risk managers or by owners of the enterprises. Nevertheless, due to it being an online questionnaire, it cannot be excluded that another individual completed it. Further studies should investigate the risk management system in different countries around the world and identify the differences between continents. The attention of academics and potential readers from the SME segment around the world can be attracted by these results.

\section{Acknowledgement}

This paper was supported by the János Bolyai Research Scholarship of the Hungarian Academy of Sciences.

\section{References}

Al Mamun, A., Kumar, N., Ibrahim, M.D. and Bin Yusoff, M.N.H., 2017. Validating the Measurement of Entrepreneurial Orientation. Economics and Sociology, [e-journal] 10(4), pp.51-66. https://doi.org/10.14254/2071-789X.2017/10-4/5

Anderson, D.R. and Anderson, K.E., 2009. Sustainability risk management. Risk Management and Insurance Review, [e-journal] 12(1), pp.25-38. https://doi.org/ 10.1111/j.1540- 6296.2009.01152.x

Aziz, N.A.A., Manab, N.A. and Othman, S.N., 2015. Exploring the Perspectives of Corporate Governance and Theories on Sustainability Risk Management (SRM). Asian Economic and Financial Review, 5(10), p.1148.

Bilan, Y., Mishchuk, H. and Pylypchuk, R., 2017. Towards sustainable economic development via social entrepreneurship. Journal of Security and Sustainability Issues, [e-journal] 6(4), pp.691-702. https://doi.org/10.9770/jssi.2017.6.4(13)

Borocki, J., Radišić, M., Sroka, W., Greblikaite, J. and Androniceanu, A., 2019. Methodology for strategic posture determination of SMEs. Inzinerine Ekonomika Engineering Economics, [e-journal] 30(3), pp. 265-277. https://doi.org/10.5755/ j01.ee.30.3.21966

Bruns, V. and Fletcher, M., 2008. Banks' risk assessment of Swedish SMEs. Venture Capital, [e-journal] 10(2), pp.171-194. https://doi.org/10.1080/13691060801946089

Brustbauer, J., 2016. Enterprise risk management in SMEs: Towards a structural model. International Small Business Journal, [e-journal] 34(1), pp.70-85. https://doi.org/10.1177/0266242614542853

Cepel, M., Stasiukynas, A., Kotaskova, A. and Dvorsky, J., 2018. Business environment quality index in the SME segment. Journal of Competitiveness, [e-journal] 10(2), pp.21-40. https://doi.org/10.7441/joc.2018.02.02

Choi, S.S., Cha, S.H. and Tappert, C.C., 2010. A Survey of Binary Similarity and Distance Measures, Journal of Systemics. Cybernetics and Informatics, 8(1), pp.43-48.

Cioccio, L. and Michael, E.J., 2007. Hazard or disaster: Tourism management for the inevitable in Northeast Victoria. Tourism Management, [e-journal] 28(1), pp.1-11. https://doi.org/10.1016/j.tourman.2005.07.015 
Dabari, I.J. and Saidin, S.Z., 2014. A theoretical framework on the level of risk management implementation in the Nigerian banking sector: the moderating effect of top management support. Procedia - Social and Behavioral Sciences, 164, pp.627-634.

Daud, W.N.W.D., Yazid, A.S. and Hussin, H.M.R., 2010. The Effect of Chief Risk Officer (CRO) On Enterprise Risk Management (ERM) Practices: Evidence from Malaysia. International Business \& Economics Research Journal (IBER), [e-journal] 9(11), pp.55-64. https://doi.org/10.19030/iber.v9i11.30

Davies, J., 2006. Risk transfer in private finance ini-tiatives (PFIs). Industry economics and Statis-tics Directorate Working Paper. [online] Department of Trade and Industry, United Kingdom Government. Available at: http://www.berr.gov.uk/files/file26074.pdf [Accessed 3 March 2019].

Deng, X., Low, S.P., Li, Q. and Xianbo, Z., 2014. Developing competitive advantages in political risk management for international construction enterprises. Journal of Construction Engineering and Management, 140(9), pp.401-404.

Du, L.W.T., Chunn, L., Wang, S., Wang, T., Shen W., Huang, M. and Zhou, Y., 2016. Enhancing engineer-procure-construct project performance by partnering in international markets: Perspective from Chinese construction companies. International Journal of Project Management, [e-journal] 34(1), pp.30-43. https://doi.org/ 10.1016/j.ijproman.2015.09.003

Dvorský, J., Schönfeld, J., Kotásková, A. and Petráková, Z., 2018b. Evaluation of important credit risk factors in the SME segment. Journal of International Studies, [e-journal] 11(3), pp.204-216. http://dx.doi.org/10.14254/2071-8330.2018/11-3/17

Dvorský, J., Popp, J., Virglerova, Z., Kovács, S. and Oláh, J., 2018a. Assessing the importance of market risk and its sources in the SME of the Visegrad Group and Serbia. Advances in Decision Sciences, 22(A), pp.1-25.

Florio, C. and Leoni, G., 2017. Enterprise risk management and firm performance: The Italian case. The British Accounting Review, 49(1), pp.56-74.

Frimpong, Y., Oluwoye, J. and Crawford, L., 2003. Causes of delay and cost overruns in construction of groundwater projects in a developing countries. Ghana as a case study. International Journal of Project Management, [e-journal] 21(5), pp.321-326. https://doi.org/10.1016/S0263-7863(02)00055-8

Gao, S.S., Sung, M.C. and Zhang, J., 2013. Risk management capability building in SMEs: A social capital perspective. International Small Business Journal: Researching Entrepreneurship, [e-journal] 31(6), pp.677-700. https://doi.org/10.1177/0266242611431094

Grigore, A.M. and Drăgan, I.M., 2015. Entrepreneurship and its Economical Value in a very Dynamic Business Environment. Amfiteatru Economic, 17(38), pp.120-132.

Henschel, T., 2006. Risk management practices in German SMEs: An empirical investigation. International Journal of Entrepreneurship and Small Business, [e-journal] 3(5), pp.554-571. https://doi.org/10.1504/IJESB.2006.010543

Herbane, B., 2010. Small business research: Time for a crisis-based view. International Small Business Journal: Researching Entrepreneurship, [e-journal] 28(1), pp.43-64. https://doi.org/10.1177/0266242609350804 
Hajduová, Z., Andrejkovič, M. and Mura, L., 2014. Utilizing experiments designed results during error identification and improvement of business processes. Acta Polytechnica Hungarica, 11(2), pp.149-166. https://doi.org/10.12700/APH.11.02.2014.02.9

Hudakova, M., Masar, M., Luskova, M. and Patak, M.R., 2018. The Dependence of Perceived Business Risks on the Size of SMEs. Journal of Competitiveness, [e-journal] 10(4), pp.54-69. https://doi.org/10.7441/joc.2018.04.04

Jafari, A., 2013. A contractor pre-qualification model based on the quality function deployment method. Construction Management and Economics, [e-journal] 31(7), pp.746-760. https://doi.org/10.1080/01446193.2013.825045

Javernick-Will, A.N. and Scott, W.R., 2010. Who needs to know what? Institutional knowledge and global projects. Journal of Construction Engineering and Management, 136(5), pp.546-557.

Jones, A.J. and Harrold, M.J., 2005. Empirical evaluation of the tarantula automatic faultlocalization technique. In: s.n., The 20th IEEE/ACM international Conference on Automated software engineering. pages 273-282, Long Beach, CA, USA, November 2005. New York, NY, USA: Association for Computing Machinery

Kljucnikov, A., Mura, L. and Sklenar, D., 2019. Information security management in SMEs: Factors of Success. Entrepreneurship and Sustainability Issues, [e-journal] 6(4), pp.2081-2094. https://doi.org/ 0.9770/jesi.2019.6.4(37)

Koval’ová, M., Hvolková, L., Klement, L. and Klementová, V., 2018. Innovation strategies in the Slovak enterprises. Acta Oeconomica Universitatis Selye, 7(1), pp.79-89.

Kot, S. and Dragon, P., 2015. Business Risk Management in International Corporations. Procedia Economics and Finance, [e-journal] 27(1), pp.102-108. https://doi.org/ 10.1016/S2212-5671(15)00978-8

Kozubíková, L., Homolka, L. and Kristalas, D., 2017. The Effect of Business Environment and Entrepreneurs' Gender on Perception of Financial Risk in the Smes Sector. Journal of Competitiveness, [e-journal] 9(1), pp.36-50. https://doi.org/10.7441/joc.2017.01.03

Leopoulos, V., 2006. Editorial. Production Planning \& Control, [e-journal] 17(3), pp.225-228. https://doi.org/10.1080/09537280500285086

Lo, H.W. and Liou, J.J.H., 2018. A novel multiple-criteria decision making-based FMEA model for risk assessment. Applied Soft Computing Journal, [e-journal] 73, pp.684-696. https://doi.org/10.1016/j.asoc.2018.09.02

Lovata, L.M. and Costigan, M.L., 2002. Empirical analysis of adopters of economic value added. Management Accounting Research, [e-journal] 13(2), pp.215-228. https://doi.org/10.1006/mare.2002.0181

McNeill, A.J., Frey, R. and Embrechts, P., 2005. Quantitative risk management: concepts. techniques and tools. Princeton series in finance. Princeton. N.J.: Princeton University Press.

Merna, T. and Al-Thani, F.F., 2007. Risk management: řízení rizika ve firmě. Brno: Computer Press.

Meyer, N., 2013. Risk management as a strategy for promoting sound financial management at Sedibeng District Municipality. Masters dissertation. North-West University. 
Meyer, N., Meyer, D. and Kot, S., 2017. The development of a process tool for improved risk management in local government. Quality - Access to Success, 18(S1), pp.425-429.

Mura, L. and Kljucnikov, A., 2018. Small Businesses in Rural Tourism and Agrotourism: Study from Slovakia. Economics \& Sociology, [e-journal] 11(3), pp.286-300. https://doi.org/ 10.14254/2071-789X.2018/11-3/17

Mura, L., 2019. Entrepreneurship internationalization - Case of Slovak family businesses. AD ALTA-Journal of Interdisciplinary Research, 9(1), pp.222-226.

Nikolova, M. and Linkova, M., 2011. Risk diversification in the agricultural sector in Bulgaria. Amfiteatru Economic Journal, 13(29), pp.305-320.

Nocco, B.W. and Stulz, R.M., 2006. Enterprise Risk Management: Theory and Practice. Journal of Applied Corporate Finance, [e-journal] 18(4), pp.8-20. https://doi.org/10.1111/j.1745-6622.2006.00106.x

Oláh, J., Virglerová, Z., Popp, J., Kliestikova, J. and Kovács, S., 2019a. The Assessment of Non-Financial Risk Sources of SMES in the V4 Countries and Serbia. Sustainability, [e-journal] 11(17), 4806, pp.1-19. https://doi.org/10.3390/su11174806

Oláh, J., Kovács, S., Virglerova, Z., Lakner, Z. and Popp, J., 2019b. Analysis and Comparison of Economic and Financial Risk Sources in SMEs of the Visegrad Group and Serbia. Sustainability, [e-journal] 11(7), 1853, pp.1-19. https://doi.org/ 10.3390/su11071853

Paape, L. and Speklé, R.F., 2012. The Adoption and Design of Enterprise Risk Management Practices: An Empirical Study. European Accounting Review, [e-journal] 21(3), pp.533-564. https://doi.org/10.1080/09638180.2012.661937

Park, H., Kang-Wook, L., Jeong, H.D. and Han, S.H., 2014. Effect of institutional risks on the performance of international construction projects. In: s.n. The Construction Research Congress 2014: Construction in a Global Network. Atlanta, Georgia, 19-21 May. s.l:s.n.

Poba-Nzaou, P., Raymond, L. and Fabi, B., 2014. Risk of adopting mission-critical OSS applications: An interpretive case study. International Journal of Operations \& Production Management, [e-journal] 34(4), pp.477-512. https://doi.org/10.1108/IJOPM03-2012-0117

Ragnedda, M., Ruiu, M. and Addeo, F., 2019. Measuring Digital Capital: an empirical investigation. New Media \& Society. [e-journal] In press. https://doi.org/10.1177/1461444819869604

Rahman, A., Belas, J., Kliestik, T. and Tyll, L., 2017. Collateral requirements for SME loans: empirical evidence from the Visegrad countries. Journal of Business Economics and Management, [e-journal] 18(4), pp.650-675. https://doi.org/10.3846/ 16111699.2017.1357050

Rauch, A., Frese, M. and Sonnentag, S., 2000. Cultural Differences in Planning/Success Relationships: A Comparison of Small Enterprises in Ireland. West Germany and East Germany. Journal of Small Business Management, 38(4), pp.28-41.

Šebestová, J. and Sroka, W., 2020. Sustainable Development Goals and SME Decisions: the Czech Republic vs. Poland. Journal of Eastern European and Central Asian Research, [e-journal] 7(1), pp.39-50. https://doi.org/10.15549/jeecar.v7i1.418 
Sheskin, D.J., 2004. Handbook of parametric and nonparametric statistical procedures. $3^{\text {rd }}$ ed. Boca Raton: Chapman \& Hall /CRC.

Spiegel, M.R. and Stephens, L.J., 2008. Schaum's outline of Theory and Problems of Statistics. London: McGraw Hill.

Stroh, P.J., 2005. Enterprise risk management at UnitedHealth Group. Strategic Finance, 87(1), pp. 26-35.

Sukumar, A., Edgar, D. and Grant, K., 2011. An investigation of e-business risks in UK SMEs. World Review of Entrepreneurship. Management and Sustainable Development, [e-journal] 7(4), 380. https://doi.org/10.1504/WREMSD.2011.042892

Terungwa, A., 2012. Risk Management and Insurance of Small and Medium Scale Enterprises (Smes) in Nigeria. International Journal of Finance and Accounting, [ejournal] 1(1), pp.8-17. https://doi.org/10.5923/j.ijfa.20120101.02

Weber, I.K., 2000. Das Planungs- und Kontrollsystem der mittelständischen Unternehmung (The planning and control system of the medium-sized enterprise). PhD Thesis. European Business School Oestrich-Winkel.

Wijethilake, Ch. and Lama, T., 2019. Sustainability core values and sustainability risk management: Moderating effects of top management commitment and stakeholder pressure. Business Strategy and the Environment, [e-journal] 28(1), pp.143-154. https://doi.org/ 10.1002/bse.2245

Witt, E., 2010. Comparing risk transfers under different procurement arrangements - initial evidence from Estonia. In: s.n. The $10^{\text {th }}$ international conference on Modern building materials, structures and techniques. Vilnius, Lithuania, 19-21 May 2010. S.1:s.n.

Woods, M., 2009. A contingency theory perspective on the risk management control system within Birmingham City Council. Management Accounting Research, [ejournal] 20(1), pp.69-81. https://doi.org/10.1016/j.mar.2008.10.003

Yadav, J.S. and Jain, M.Y.A., 2014. Risk Assessment Models and Methodologies. International Journal of Scientific Research And Education, 1(6), pp.135-142.

Zainol, N.R., Al Mamun, A., Ahmad, G. and Simpong, D.B., 2018. Human Capital and Entrepreneurial Competencies towards Performance of Informal Microenterprises in Kelantan, Malaysia. Economics and Sociology, [e-journal] 11(4), pp.31-50. https://doi.org/10.14254/2071-789X.2018/11-4/2

Zhao, X., Hwang, B.G. and Low, S.P., 2015. Enterprise risk management in international construction firms: Drivers and hindrances. Engineering. Construction and Architectural Management, [e-journal] 22(3), pp. 347-366. https://doi.org/ 10.1108/ECAM-09-2014-0117 